\title{
49
}

\section{Erratum to: "Representing the Maze/Long Kesh Prison in Northern Ireland: Conflict Resolution Centre and Tourist Draw or Trojan Horse in a Culture War?"}

\author{
William J.V. Neill
}

The Publisher regrets that the caption of Fig. 12.5 was incorrect. The caption should read " 2004 photograph by William J.V. Neill of a prison cell in the Maze hospital block”.

The original version of this chapter was revised.

An erratum to this chapter can be found at DOI 10.1057/978-1-137-56135-0_12 